\title{
Study on Radon Emanation from Selected Cement Samples by using Nuclear Track Detector (CR 39)
}

\author{
Khalid H. Abass, Ali Obies Muhsen Al Mayyali, Inaam H. Kadhim* \\ Department of Physics, College of Education for Pure Sciences, University of Babylon, Iraq \\ *E-mail address: anaam_hani@yahoo.com
}

\begin{abstract}
In this work, we have study the concentration of radon gas in seven cement samples from different regions in Iraq (Kofa, Sulaymaniya, Kubesa, Karbala, Al-Kaem, Basra, and Almas cement) by using alpha-emitters registrations that emitted from radon gas in CR-39 nuclear track detector. Sealed-cup technique that used in this study to determine the alpha emitters from radon gas. The results obtained shown that the highest average radon gas concentration in cement samples which was $\left(55.16 \mathrm{~Bq} / \mathrm{m}^{3}\right)$ for Almas samples, while the lowest average radon gas concentration in cement samples which was $\left(24.13 \mathrm{~Bq} / \mathrm{m}^{3}\right)$ for Karbala samples. The current results show that the radon gas concentration in all cement samples that studied is below the allowed limit from International Commission of Radiation Protection (ICRP) agency.
\end{abstract}

Keywords: Radon gas; CR-39 detector; cement

\section{INTRODUCTION}

High concentration of radon and its decay product is widely known to be dangerous to human health. It is possibly associated with different types of cancer and especially with lung cancer. Emission percentage of radon into atmosphere coming from a few meters above the ground is at least $80 \%$ [2]. Radon is the main a natural radioactive gas. As a noble gas, Radon has the ability to spread through solids and air mixing with air which is found everywhere and cannot be avoided [3]. It has very serious effects on human health due to large scale abundance of its parents and its longer half life. Radon has been considered as second leading cause of lung cancer after smoking [4]. A $2.4 \mathrm{mSv}$ average annual dose has been estimated from natural radiation sources to the world population. Two-third of average annual dose is the internal exposure and one-third is external exposure [5]. Inhalation of radon gas and its daughters will expose the lung tissue to short-lived alpha emitting radionuclides, which will increase the risk of lung cancer. One of the major factors of increasing skin cancer is radon gas, where it is due to the deposition of radon on the skin, the alpha particles are suspected to include damage to the epithelial cell. Kidney related diseases have also been observed in some people exposed to radon. The reason is that kidney receives the highest dose compared to other body organs, after radon is transferred from the lung to the kidney by blood [6].

Different sources are responsible for the presence of radon and its daughters in houses. One of the major sources of concentration of radon in houses is the cement [7]. 
The radiological impact from the above nuclides is due to radiation exposure of the body by the gamma rays and irradiation of the lung tissues from inhalation of Radon and its progeny [8]. From the natural risk point of view, it is necessary to know the dose limits of public exposures and to measure the natural environmental radiation level provided by ground, air, water, foods, building interiors, etc., for the estimation of the exposures to natural radiation sources. [9].

Cement is a commonly used building construction material. The natural level of radioactivity in cement gives rise to internal and external indoor exposure. The external exposure is caused by gamma radiation originating from the members of the uranium $\left({ }^{238} \mathrm{U}\right)$ and thorium $\left({ }^{232} \mathrm{Th}\right)$ decay series, and also from potassium $\left({ }^{40} \mathrm{~K}\right)[10]$. The knowledge of radon levels in building is important in assessing population exposure.

The use of solid state nuclear track detectors (SSNTDs) has already become a wellknown technique which has been widely applied in monitoring concentrations by recording their emitted alpha particles[6,10].The aim of the present work is to determine the alpha particles concentration in Iraqi cement samples by using alpha-emitters registrations which are emitted form samples by using nuclear track detector (CR-39).

\section{EXPERIMENT PART}

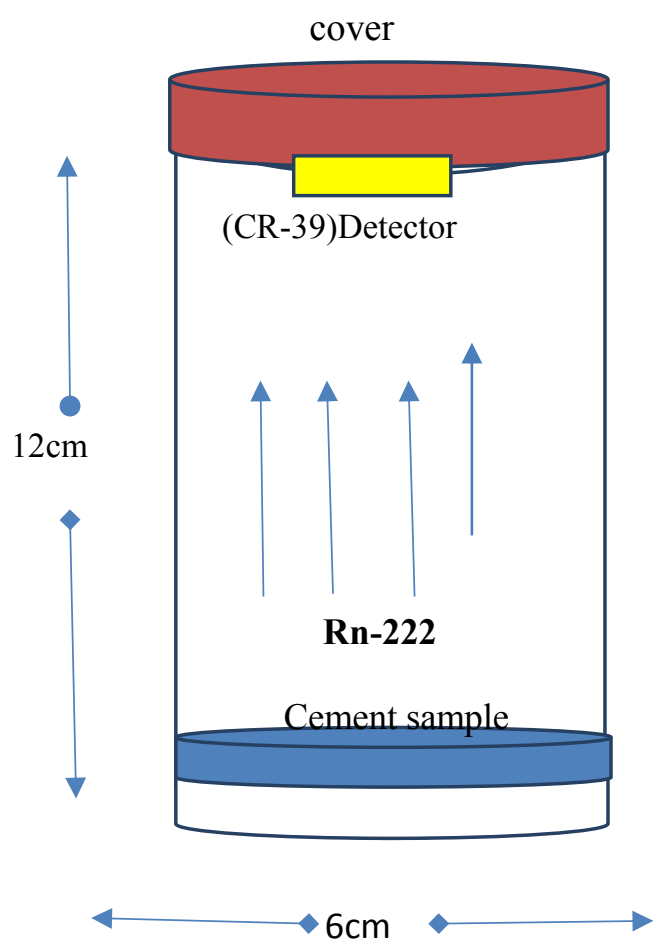

Fig. 1. A schematic diagram of the sealed-cup technique.

The determination of the concentrations of alpha particles emitted from radon gas in cement samples were performed by using the nuclear track detector (CR-39) of thickness $250 \mu \mathrm{m}$ and area of about $\left(1 * 1 \mathrm{~cm}^{2}\right)$. The radon gas concentration in cement samples was obtained by using the sealed-cup technique as shown in Fig. 1. 
After the irradiation time (six weeks), the CR-39 track detectors were etched in $6.25 \mathrm{~N}$ (by $\mathrm{NaOH}$ solution) at temperature of $60^{\circ} \mathrm{C}$ for 5 hours, and the tracks density were recorded using an optical microscope (type ALTAY BIO-1007)with magnification of (400 x). The density of tracks $(\rho)$ in the samples were calculated according to the following relation [11].

Track density $(\rho)=\frac{\text { Average numberof total pits (tracks) }}{\text { Area of feild view }}$

The radon gas concentration in the cement samples were obtained by the comparison between track densities registered on the detectors of the sample and that of the standard cement samples which are shown in Fig. 2, using the relation [12]

$\mathrm{C}_{\mathrm{X}}=\rho_{\mathrm{X}}\left(\mathrm{C}_{\mathrm{S}} / \rho_{\mathrm{S}}\right)$

where :

$\mathrm{C}_{\mathrm{X}}$ : alpha particles concentration in the unknown sample.

$\mathrm{C}_{\mathrm{s}}$ : alpha particles concentration in the standard sample.

$\rho_{\mathrm{x}}$ : track density of the unknown sample $\left(\operatorname{track} / \mathrm{mm}^{2}\right)$.

$\rho_{\mathrm{s}}$ : track density of the standard sample $\left(\operatorname{track} / \mathrm{mm}^{2}\right)$.

$$
\text { Slope }=\left(\mathrm{p}_{\mathrm{S}} / \mathrm{C}_{\mathrm{S}}\right)=0.145\left(\text { track. } \mathrm{m}^{3} / \mathrm{mm}^{2} \cdot \mathrm{Bq}\right)
$$

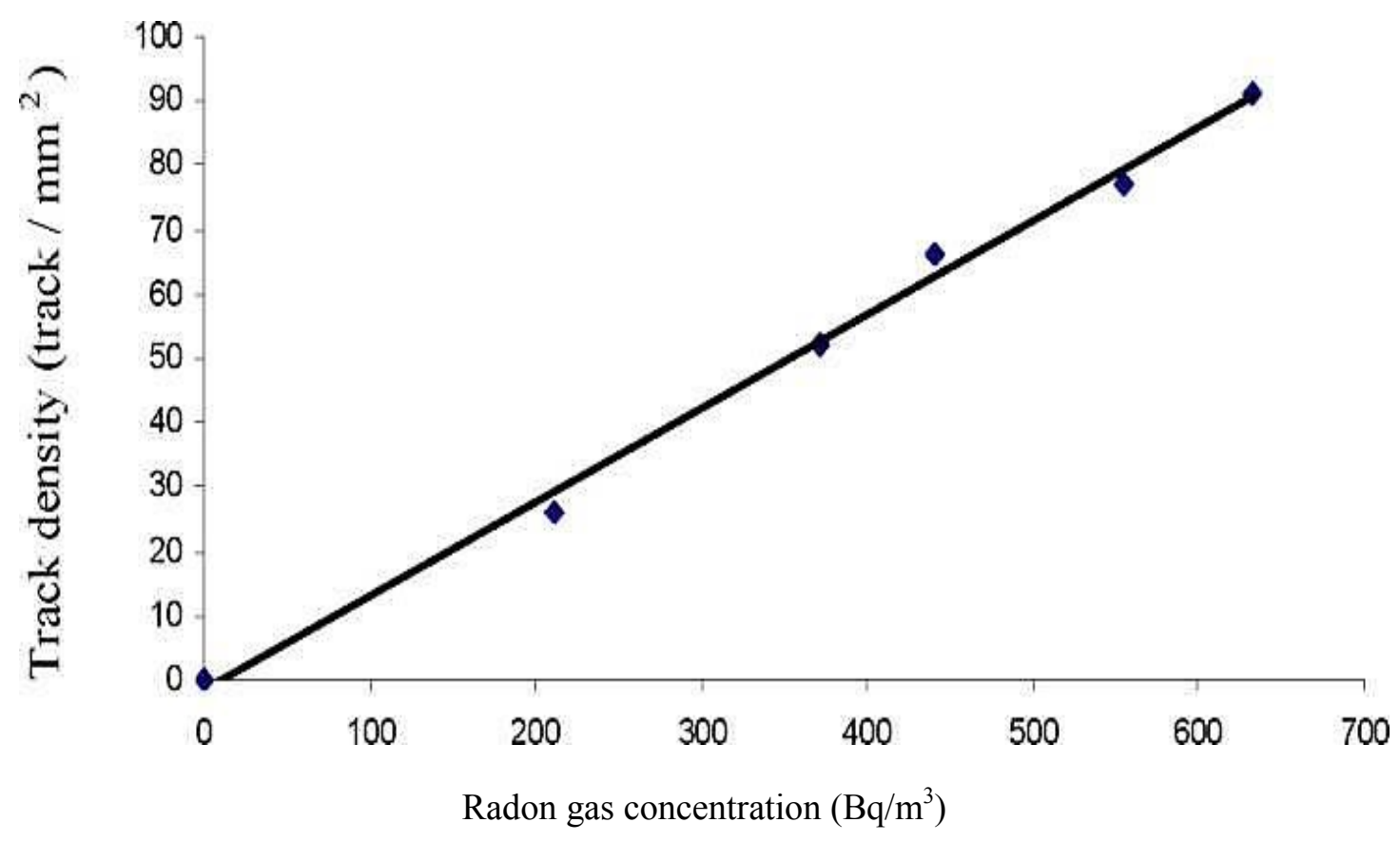

Fig. 2. Relation of radon gas concentration and track density in standard samples [13]. 
Table 1. Radon gas concentration for cement samples from different Province.

\begin{tabular}{|c|c|c|c|c|c|c|c|}
\hline \multirow{2}{*}{$\begin{array}{l}\text { No. of } \\
\text { sample }\end{array}$} & \multirow{2}{*}{$\begin{array}{c}\text { Origin of } \\
\text { cement sample }\end{array}$} & \multirow[b]{3}{*}{ Track density (Track. $\mathrm{mm}^{-2}$ ) } & \multicolumn{5}{|c|}{ Samples } \\
\hline & & & 1 & 2 & 3 & 4 & Mean \\
\hline \multirow{2}{*}{1} & \multirow{2}{*}{$\begin{array}{c}\text { Iraq } \\
\text { (Alkaem) }\end{array}$} & & 4 & 6 & 9 & 7 & 6.5 \\
\hline & & Radon Concentration $\left(\mathrm{Bq} / \mathrm{m}^{3}\right)$ & 27.58 & 41.13 & 62.06 & 48.27 & 44.82 \\
\hline \multirow{2}{*}{2} & \multirow{2}{*}{$\begin{array}{l}\text { Iraq } \\
\text { (Basrah) }\end{array}$} & Track density (Track . $\mathrm{mm}^{-2}$ ) & 7 & 9 & 7 & 6 & 7.25 \\
\hline & & Radon Concentration $\left(\mathrm{Bq} / \mathrm{m}^{3}\right)$ & 48.27 & 62.06 & 48.27 & 41.37 & 49.99 \\
\hline \multirow{2}{*}{3} & \multirow{2}{*}{$\begin{array}{c}\text { Iraq } \\
\text { (Karbala) }\end{array}$} & Track density (Track . mm ${ }^{-2}$ ) & 3 & 5 & 2 & 4 & 3.5 \\
\hline & & Radon Concentration $\left(\mathrm{Bq} / \mathrm{m}^{3}\right)$ & 20.68 & 34.48 & 13.79 & 27.58 & 24.13 \\
\hline \multirow{2}{*}{4} & \multirow{2}{*}{$\begin{array}{c}\text { Iraq } \\
\text { (Almas) }\end{array}$} & Track density (Track . $\mathrm{mm}^{-2}$ ) & 6 & 10 & 7 & 9 & 8 \\
\hline & & Radon Concentration $\left(\mathrm{Bq} / \mathrm{m}^{3}\right)$ & 41.37 & 68.96 & 48.27 & 62.06 & 55.16 \\
\hline \multirow{2}{*}{5} & \multirow{2}{*}{$\begin{array}{c}\text { Iraq } \\
\text { (Kbesa) }\end{array}$} & Track density (Track. $\mathrm{mm}^{-2}$ ) & 4 & 5 & 6 & 3 & 4.5 \\
\hline & & Radon Concentration $\left(\mathrm{Bq} / \mathrm{m}^{3}\right)$ & 27.58 & 34.48 & 41.37 & 20.68 & 31.03 \\
\hline \multirow{2}{*}{6} & \multirow{2}{*}{$\begin{array}{l}\text { Iraq } \\
\text { (Kofa) }\end{array}$} & Track density (Track. $\mathrm{mm}^{-2}$ ) & 6 & 11 & 4 & 5 & 6.5 \\
\hline & & Radon Concentration $\left(\mathrm{Bq} / \mathrm{m}^{3}\right)$ & 41.37 & 75.85 & 27.58 & 34.48 & 44.82 \\
\hline \multirow{2}{*}{7} & \multirow{2}{*}{$\begin{array}{c}\text { Iraq } \\
\text { (Sulaymaniyah) }\end{array}$} & Track density (Track . $\mathrm{mm}^{-2}$ ) & 4 & 4 & 5 & 3 & 4 \\
\hline & & Radon Concentration $\left(\mathrm{Bq} / \mathrm{m}^{3}\right)$ & 27.58 & 27.58 & 34.48 & 20.68 & 27.58 \\
\hline
\end{tabular}

\section{RESULT AND DISCUSSION}

In this work, we have study the radon gas concentration in seven cement samples from different origins in Iraq(Kofa, Sulaymaniya, Kubesa, Karbala, Al-Kaem, Basra, and Almas cement) by using alpha-emitters registration which are emitted from radon gas in CR-39 nuclear track detector.

Table 1 represent the radon gas concentrations for cement samples in different origins in Iraq. It can be noticed that, the highest average radon gas concentration in cement samples was found in Almas cement sample, which was $\left(55.16 \mathrm{~Bq} / \mathrm{m}^{3}\right)$, while the lowest average radon gas concentration in cement samples was found in Karbala cement sample, which was $\left(24.13 \mathrm{~Bq} / \mathrm{m}^{3}\right)$. The present results show that the radon gas concentration in all cements samples are below the allowed limit from International Commission of Radiation Protection 
(ICRP) agency which is $\left(200 \mathrm{~Bq} / \mathrm{m}^{3}\right)$ in soil sample [1].Thus they are safe to be used as building materials according to the international recommendations. The values were found minimum for cement samples, therefore, from the health point of view it is suggested that cement houses are safer than mud houses. The work was designed to study the radon level, radium activity and annual effective dose from building materials. Further studies are needed to determine radon level and natural radioactivity in water, soil, food, and vegetation samples and their risk factors should be investigated.

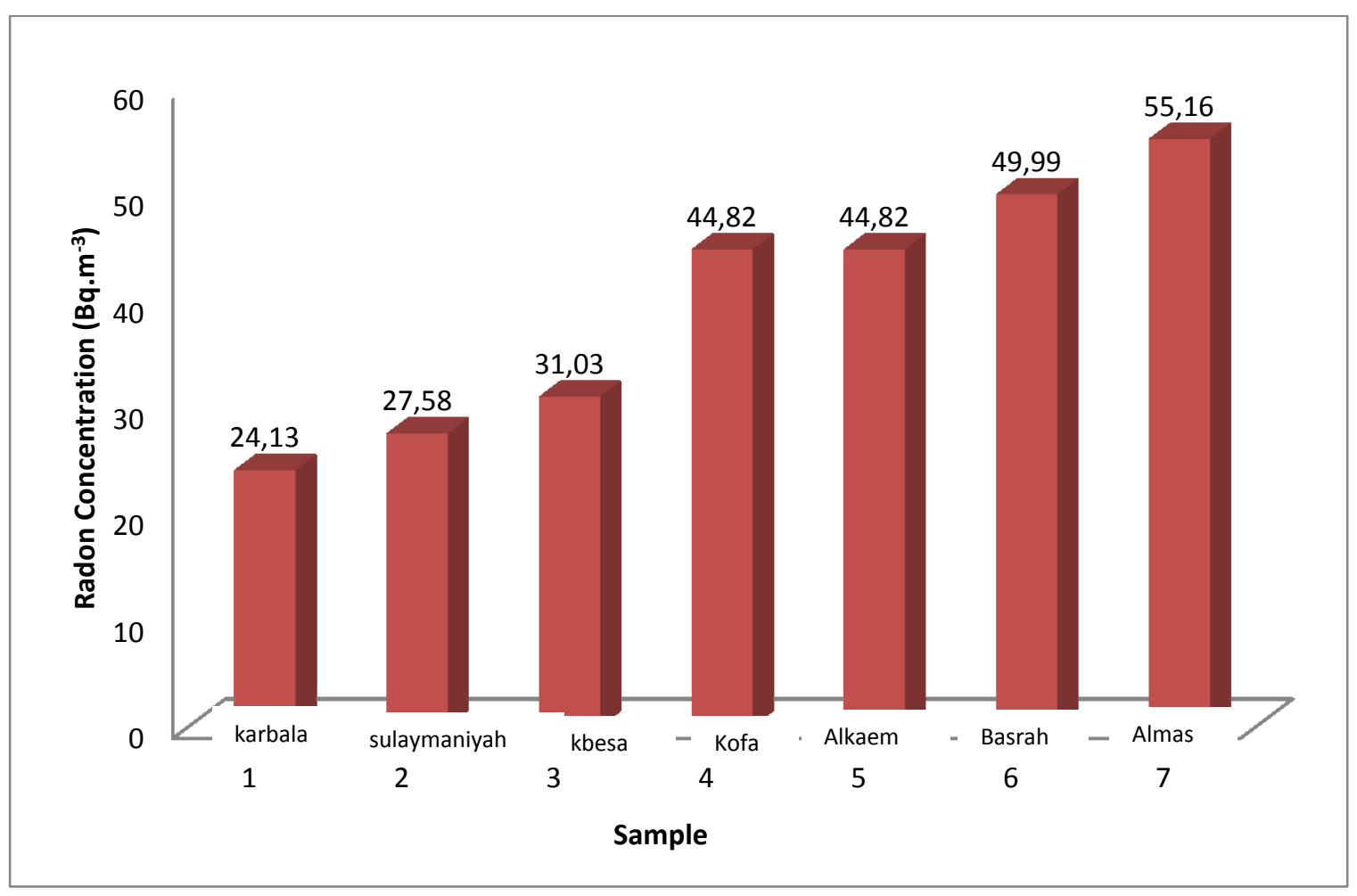

Fig 3. Relation of Activity radon gas concentration and samples.

\section{CONCLUSIONS}

From the present work, it can be concluded that the highest average radon gas concentration in cement samples was found in Almas sample, which was $\left(55.16 \mathrm{~Bq} / \mathrm{m}^{3}\right)$, while the lowest average radon gas concentration in cement samples wasfound in Karbala sample, which was $\left(24.13 \mathrm{~Bq} / \mathrm{m}^{3}\right)$. The present results show that the radon gas concentration in cement samples is below the allowed limit from ICRP $[1,8]$. 


\section{References}

[1] ICRP (International Commission on Radiological Protection),"Human respiratory tract model for radiological protection", (1994) ICRP Publication 66, Annals of the ICRP 24(1-4), Pergamon Press.

[2] Shweikani R., T. Giaddui, S. Durrani, Radiat. Measurem 25 (1995) 581-584.

[3] C. Canbazoğlu, M. Doğru, N. çelebi, G. Kopuz, Journal of Radioanalytical and Nuclear Chemistry 292 (2012) 375-380.

[4] IARC Monographs on the Evaluation of Carcinogenic Risks to Humans, 1st Edn., IARC Press, Lyon, France, (2004), pp. 1452.

[5] Wang Z, Int. Congress Series 1225 (2002) 39-46.

[6] Henshaw D.L., J.P. Eatough and R.B. Richardson, Radon as a causative factor in induction of myeloid leukaemia and other cancers. Lancet, ,(1990), 6736 (90) 91071-H.

[7] M., R.P, Nain Chauhan, S.K. Chakarvarti, Iran. J. Radit. Res. 3(4) (2006) 171-176.

[8] Khalid H. Hataf and Inaam Hani Kadhim, Journal of Babylon University/Pure and Applied Sciences 21(7) (2013).

[9] A.K. Mahur, R.G. Rajesh Kumar, Sonkawade, D. Sengupt, Rajendr Prasad, Nucl. Instr. \& Methods in Phy. Res. B 266 (2008) 1591-1597.

[10] Yi Y.W, "Experimental determination of parameters of tracks on solid state nuclear track detectors from alpha particles with different incident energies and angles", M.Sc. Thesis, City University of Hong Kong, (2004).

[11] Nisar Ahmad, Mohamad Suhaimi Jaafar, Sohail Aziz Khan, Tabassum Nasir, Sajjad Ahmad and Muhammad Rahim, American Journal of Applied Sciences 11(2) (2014) 240-247.

[12] Khalid Haneen Abass, Journal of Babylon University/Pure and Applied Sciences 22(6) (2014).

[13] H. L. Mansour, M. S. Karim, R. D. Al-Alawy and K. A. Mishjil, "The Determination of radon gas concentration in soil and water samples in Baghdad and Anbar governorates by using nuclear track detector (CR-39)" ,the seventeenth scientific conference of the college of education Al-Mustansiriyah University, 2010, p. 632-647. 